\title{
CURRENT LIVESTOCK SCENARIO IN INDIA AND THEIR CONTRIBUTION TO NATIONAL ECONOMY
}

\author{
N. BRINDHA \\ Research Associate Department of Veterinary and Animal science Tamil Nadu \\ Agricultural University, Coimbatore, Tamil Nadu, India
}

\begin{abstract}
Livestock sector is one of the main sectors that play a very important role, in Indian rural population welfare. A major section of India's labor force is employed by the livestock sector. It provides draft power in large share, which is used for crop land cultivation. Livestock sector of India is one of the world's largest livestock sectors holding $11.6 \%$ of livestock population in the world. Livestock sector and fisheries sectors contributes $4.4 \%$ and $1 \%$, respectively to the national economy in terms of Gross Domestic Product (GDP). The gross value added by the livestock sector to agricultural sector has increased in 2014-2015 to 26.9\%. This sector is performing well in terms of value addition, production and export of fishery, dairy, poultry, wool and other production. It also acts as an important source for foreign exchange.
\end{abstract}

KEYWORDS: Livestock, Poultry, Economy, Population, Production \& Trade

Received: Sep 16, 2017; Accepted: Oct 04, 2017; Published: Oct 28, 2017; Paper Id.: IJASRDEC201719

\section{INTRODUCTION}

Livestock sector plays a very important role in Indian economy. It provides livelihood to $2 / 3^{\text {rd }}$ of rural population. India has the largest livestock population and has a vast livestock resource. In the rural area of India, livestock rearing is one of the main incomes for the farmers. Livestock includes cattle, goat, buffalo, and pig and poultry species. It also acts as a source of protein in the form of meat, milk and egg to the households. Welfare of Indian rural population is ensured by the animal husbandry sector, as the livelihood of majority of the farmers depend on animal husbandry. Livestock sector provides sustainable source of income for many marginal and small farmers. It also provides supplementary employment and leads to rural economy leverage and a profession with high export potential. Further to this, this sector also offers essential food products like meat, milk, eggs along with raw materials like wool, manure, draught powder and hides for industries. It emerges as an engine for the growth of agriculture and is also considered as one of the export earning potential sectors. Its contribution to the environment conservation is also significant. It also adds income from the production of crop and absorbs income shocks that are caused due to the crop failure. It provides continuous stream of employment and income to the people of rural community and decreases seasonality in livelihood patterns. $70 \%$ of rural population includes the marginal households and landless. Rural poverty is mostly concentrated on this $70 \%$ of the population, which owns majority of the livestock that are small or marginal. Land scarce poor households keep small animals like goats, sheep, poultry and pigs, for their commercial purposes, because of their low operational costs and low initial investment.

Land scarce poor households for commercial purposes, because of their low initial investment and 
operational costs.

\section{METHODS AND DATA}

This paper is written based on extensive consideration of data from multiple research articles, annual reports, proceedings of conferences and the information published by Department of Animal Husbandry Dairying \& Fisheries (DAHDF) from time to time.

As the source of information, the report of the Working Group on Animal Husbandry and Dairying for the Twelfth Five Year Plan (2012-2017) by Planning Commission, Government of India were used. The major source of information was provided by the Basic Animal Husbandry Statistics (2016). For the present compilation, report of National Accounts Division published by Ministry of Statistics and Programme Implementation and Annual Report (2015-16) of Ministry of Agriculture, Government of India were also reviewed.

\section{LIVESTOCK POPULATION}

India has the largest livestock population of about 512.06 million as per the $19^{\text {th }}$ livestock census. There is a decline of percentage change of livestock population at the rate of 3.33 . At world level, India stands in $1^{\text {st }}$ place with the population level of about 105.7 million. In cattle, India stands $2^{\text {nd }}$ with 190.9 million population in cattle population and goat population of about 135.2 million. India has the $2^{\text {nd }}$ largest poultry market and stands $3^{\text {rd }}$ in sheep population with 65 million, $7^{\text {th }}$ in poultry population of about 729.2 million, $10^{\text {th }}$ in Camel population and $5^{\text {th }}$ in Duck population. The population of livestock has increased in Gujarat (15.36\%), Assam (10.77\%), Uttar Pradesh (14.01\%), Bihar (8.56\%), Punjab (9.57\%), Meghalaya (7.41\%), Sikkim (7.96\%) and Chhattisgarh (4.34\%). India is first in the buffalo population with 105.3 million buffaloes, second in cattle and goat population with 140.5 million goats, third in sheep population with 72 million sheeps, fifth in ducks and chicken population and tenth in camel population in the world. Please refer table 3, for this information.

\section{GROSS VALUE ADDED OF LIVESTOCK AND FISHERIES SECTOR IN INDIA}

Gross value added of livestock is around 4.4\% as per the basic animal husbandry statistical data of the year 2014-15. There is an increase of $26.9 \%$ in the share of gross value added of livestock sector to agricultural sector in the year $2014-$ 15. Even during the slow time, the growth of the livestock sector remained 1.5 times higher than the crop sector. This showed the critical situation in cushioning growth of agriculture. The output value from livestock was Rs. 500405 million in 2014-15 at current prices.

\section{MILK PRODUCTION}

At the world level, India stands first in milk production. Milk and its products are very important food items for the young children. The milk production status of our country in 1950-51 was 17.0 million tonnes. Later, the government had implemented policies, in improving the milk production over the period of time. The growth rate of milk production has increased annually, from 146.3 million tonnes (2014-15) to 155.5 million tonnes (2015-16). Higher demand increase has been indicated by the estimates of Planning Commission of India (182 million tons by the year 2021-22).

In 1950-51, the availability of milk was at 130g/day per capita and this would be gradually increased, with a fluctuation in the intermittent period. In the year 2015-16, the per capita availability of milk was 337g/day/person, 
consumed in India as per the reports of $12^{\text {th }}$ Five year plan, which is above the recommendation of ICMR of 280/g/day/person. It has been observed that 9 states have per capita availability more than the national average level. In these states, Punjab has been found to be the highest milk consuming states with per person consuming $1032 \mathrm{~g} / \mathrm{day}$. The lowest milk consuming state is Daman \& Diu with the consumption of $10 \mathrm{~g} / \mathrm{day}$.

\section{Species Wise Milk Contribution}

- Indigenous buffalo contributes $36 \%$ of the milk production, crossbred cattle contributes $26 \%$ of milk production, $9 \%$ by non-descript cattle, $12 \%$ by indigenous cattle, $1 \%$ by exotic cattle, $13 \%$ by non-descript buffalo and $3 \%$ by goat.

\section{State Wise Milk Production}

- In India, Uttar Pradesh stands first in milk production contributing $17 \%$ of total milk production. This is followed by Rajasthan with $11.9 \%$ milk production, $7.9 \%$ by Gujarat, $7.8 \%$ by Madhya Pradesh, $4.1 \%$ by Karnataka, $4.7 \%$ by Tamil Nadu, $5.4 \%$ by Haryana, $5.3 \%$ by Bihar, $3.2 \%$ by West Bengal, $2.9 \%$ by Telangana, $1.7 \%$ by Kerala, $1.5 \%$ by Jammu \& Kashmir, $1.2 \%$ by Odisha and $1.2 \%$ by Jharkhand.

\section{EGG PRODUCTION}

In India, the poultry industry has become one of the steadily growing industries. The production of egg has increased substantially from 1832 million from 1950-51 to 82929 million in 2015-16. In 1950-56, the availability of eggs national average per capita was 5 egg/ annum and this has increased steadily and reached 66eggs/annum in the year 201516. This is actually below the recommendation of ICMR, which are $365 \mathrm{eggs} / \mathrm{annum}$. It is found that 8 states have highest per capita availability than the national average. In these 8 states, Andhra Pradesh ranks first with 289eggs/annum, followed by Tamil Nadu in the $2^{\text {nd }}$ place consuming $231 \mathrm{egg} /$ annum. The lowest egg consuming state is Daman \& Diu, with produce of 8 eggs/ annum.

\section{Species Wise Contribution}

Improved fowl contributes $85.9 \%$ of the egg production, desi fowl contributes $12.82 \%$ of the egg production, and desi duck contributes $1.01 \%$ and $0.28 \%$ by the improved duck.

\section{State Wise Contribution}

National average has been crossed by 7 states and 2 Union territories. Tamil Nadu is the largest egg producer in Indian with $19.4 \%$ of total egg production in India. Andhra Pradesh ranks second with $18.89 \%$ of egg production and $13.5 \%$, by Telangana.

\section{MEAT PRODUCTION}

In the year 2015-16, the total production of meat reached 7 million tonnes in India. The annual growth rate was decreased at the rate of $4.92 \%$.

\section{Species Wise Contribution}

Poultry contributes $46 \%$ of meat production, buffalo contributing $23 \%$, goat contributing $13 \%$, sheep contributing $7 \%$, pig contributing $6 \%$ and cattle contributing $5 \%$. 


\section{State Wise Contribution}

Among all the Indian states, Uttar Pradesh ranks first in meat production with $20.2 \%$ of total meat production in India. West Bengal ranks second with the contribution of $9.8 \%$ followed by Maharashtra contributing 9.6\%. Uttar Pradesh produces maximum meat from pig and buffalo. Maximum meat from poultry and sheep is produced by Andhra Pradesh, whereas maximum goat meat is produced by West Bengal. In India, the availability of meat is about $15 \mathrm{~g} / \mathrm{person} / \mathrm{day}$, which is lower than the recommendation of ICMR of $30 \mathrm{~g} / \mathrm{person} / \mathrm{day}$.

\section{WOOL PRODUCTION}

The total wool production in India was 43.6 million $\mathrm{kg}$ in the year 2015-16.

\section{Species Wise Contribution}

$70 \%$ of wool production is contributed by Ewe, whereas $18 \%$ contribution is done by Ram followed by $12 \%$ by lamb. A large negative growth of $9.47 \%$ was registered in the annual growth of wood production in the year 2015-16. Rajasthan ranks first in the wool production contributing 30.8\% followed by Karnataka ranking second with $18.8 \%$ and Jammu \& Kashmir contributing third with $15.8 \%$.

\section{GROWTH RATE OF LIVESTOCK PRODUCTS}

The growth rate was highest for meat among all the livestock products with $4.92 \%$ during 2015-16. This is followed by the egg, milk and wool with $5.95 \%, 5.51 \%$ and $-1.84 \%$ respectively. Maximum annual growth was recorded in Uttar Pradesh for milk and meat, Tamil Nadu for egg and Rajasthan for wool production (BAHS, 2016). Table 1 depicts the growth trend of significant livestock products.

\section{TRADE IN LIVESTOCK SECTOR}

India is the net exporter of deboned frozen buffalo meat. Exports have grown in the last few years to record the levels. India ranks third, whereas Brazil and US stands first and second respectively to annually export more than 1 million tonnes of bovine meat. The increase in the exports is mainly due to the lower rate of Indian buffalo meat. The buffalo meat export has reached 1.15 million tons in 2012, whereas it was 1.02 million tons in 2011 . The production in 2012 is $12 \%$ higher than the production in 2011. Though India stands in top tier in the production of various livestock commodities, India is still a tiny player in the livestock trade's global market. Kumar 2010 says that India does not even contribute $1 \%$ of world's export of the livestock products.

\section{FUTURE OF TRADE IN LIVESTOCK PRODUCTS}

The future domestic requirement of multiple livestock based products and their production levels determines the most significant aspects on future export potentiality of India. In future, if there is sufficient production of these products, which also meets the domestic demands, the remaining products would be exported to the other countries, provided that the international market and the price should remain favorable. The future growth in Indian export will also rely on production deficit recognized in the different developing and the developed countries of the world. The shortage in the production of other countries would also act as the engine of Indian export growth. 


\section{CONSTRAINTS OF LIVESTOCK SECTOR IN INDIA}

To adopt the improved technologies and quality inputs, lack of market access acts as a hindrance. There is a lack of transparency and underdevelopment in the livestock market and livestock products, except for poultry and milk products. These are sometimes dominated by informal market intermediaries who also exploit the producers. There are also inadequate facilities for slaughtering. $50 \%$ of the total meat production is contributed by make-shift and un-registered slaughter houses. Transaction and marketing costs of livestock products are high taking $15-20 \%$ of the sale price. Due to the increased stress on the limited natural resources, the number-driven growth on the livestock production may not have sustainability in long run. The growth in the future can come only from the improvements in service delivery systems and technology leading to processing, accelerated productivity and marketing.

\section{CONCLUSIONS}

A significant amount of livestock resources in the world come from India livestock industry. Livestock sector back up the national economy as well as the socio-economic growth of India. It is also performing well by offering outstanding contribution and great potential in agricultural sector over the past few years. Besides, it also contributes high productivity, value addition and export of fishery, dairy, poultry, wool and other products. When the performance is on the positive side, there are also few threats like unorganized livestock market and social taboo, which should be re-corrected to take the global market opportunities.

\section{REFERENCES}

1. Annual report 2014-15, dept. of Animal Husbandry Dairying and Fisheries Ministry of Agriculture and Family Welfare, Govt. Of India, New Delhi.

2. Basic Animal Husbandry Statistics 2015-16. Planning Commission. 2012. Report of the Working Group on Animal Husbandry and Dairying for the Twelfth Five Year Plan 2012-2017. Government of India, New Delhi.

3. Kumar, Anjani 2010. Export of livestock products from India: Performance,Competitiveness and Determinants. Agricultural Economics Research Review. 23: 57-67.

Table 1

\begin{tabular}{|l|l|c|c|c|}
\hline \multicolumn{5}{|c|}{ Compound Annual Growth Rate Of Milk, Egg And Wool During The Five Years Plans - All India } \\
\hline \multicolumn{1}{|c|}{ Compound Annual Growth Rate (\%) } \\
\hline \multicolumn{1}{|c|}{ Plan } & \multicolumn{1}{|c|}{ Year } & Milk & Eggs & Wool \\
\hline 5th Plan & (1975-76 to 1979-80) & 2.91 & 3.5 & 1.49 \\
\hline 6th Plan & (1980-81 to 1984-85) & 6.42 & 8.4 & 2.67 \\
\hline 7th Plan & (1985-86 to 1989-90) & 4.37 & 7.23 & 1.88 \\
\hline 8th Plan & (1992-93 to 1996-97) & 4.41 & 4.58 & 0.8 \\
\hline 9th Plan & (1997-98 to 2001-2002) & 4.08 & 7.29 & 2.2 \\
\hline 10th Plan & (2002-03 to 2006-07) & 3.64 & 5.61 & -1.77 \\
\hline 11th Plan & (2007-08 to 2011-12) & 4.33 & 5.53 & 0.46 \\
\hline 12th Plan* & (2012-13 to 2016-17) & 5.51 & 5.95 & -1.84 \\
\hline
\end{tabular}


Table 2

\begin{tabular}{|c|c|c|c|c|c|c|c|c|c|c|c|c|}
\hline \multicolumn{13}{|c|}{ Percentage Change Of Livestock \& Poultry Population During 1951 to 2012-All India } \\
\hline \multicolumn{13}{|c|}{$(\%$ Change $)$} \\
\hline Species & $\begin{array}{c}\text { 1951- } \\
56\end{array}$ & $\begin{array}{c}1956- \\
61\end{array}$ & $\begin{array}{c}1961- \\
66\end{array}$ & $\begin{array}{c}1966- \\
72\end{array}$ & $\begin{array}{c}1972- \\
77\end{array}$ & $\begin{array}{c}1977- \\
82\end{array}$ & $\begin{array}{c}1982- \\
87\end{array}$ & $\begin{array}{c}1987- \\
92\end{array}$ & $\begin{array}{c}1992- \\
97\end{array}$ & $\begin{array}{l}1997- \\
2003\end{array}$ & $\begin{array}{c}\text { 2003- } \\
07\end{array}$ & $\begin{array}{c}2007 \\
-12\end{array}$ \\
\hline 1. Cattle & 2.19 & 10.65 & 0.34 & 1.19 & 0.95 & 6.92 & 3.76 & 2.45 & -2.79 & -6.89 & 7.50 & -4.10 \\
\hline $\begin{array}{l}2 . \\
\text { Buffaloe } \\
s\end{array}$ & 3.46 & 14.03 & 3.52 & 8.30 & 8.01 & 12.55 & 8.87 & 10.85 & 6.78 & 8.90 & 7.58 & 3.19 \\
\hline 3. Sheep & 0.51 & 2.29 & 5.47 & -5.66 & 2.50 & 18.93 & -6.28 & 11.12 & 13.21 & 6.92 & 16.41 & -9.07 \\
\hline 4. Goats & 17.37 & 9.93 & 6.08 & 4.49 & 12.00 & 25.99 & 15.71 & 4.60 & 6.45 & 1.34 & 13.01 & -3.82 \\
\hline $\begin{array}{l}\text { 5.Horses } \\
\& \text { ponies }\end{array}$ & 0.00 & $\begin{array}{c}- \\
13.33 \\
\end{array}$ & $\begin{array}{c}- \\
15.38 \\
\end{array}$ & -18.18 & 0.00 & 0.00 & -11.11 & 2.50 & 1.22 & -9.64 & -18.60 & 2.12 \\
\hline $\begin{array}{l}6 . \\
\text { Camels }\end{array}$ & 33.33 & 12.50 & 11.11 & 10.00 & 0.00 & -1.82 & -7.41 & 3.00 & -11.65 & -30.77 & -18.20 & 22.63 \\
\hline 7. Pigs & 11.36 & 6.12 & -3.85 & 38.00 & 10.14 & 32.50 & 5.56 & 20.32 & 3.91 & 1.73 & -17.66 & -7.54 \\
\hline 8.Mules & $\begin{array}{c}- \\
33.33\end{array}$ & 25.00 & 60.00 & 0.00 & 12.50 & 44.44 & 30.77 & 11.76 & 15.79 & -18.18 & -22.10 & 43.07 \\
\hline $\begin{array}{l}\text { 9.Donke } \\
\text { ys }\end{array}$ & $\begin{array}{c}- \\
15.38 \\
\end{array}$ & 0.00 & 0.00 & -9.09 & 0.00 & 2.00 & -5.88 & 1.04 & -9.28 & -26.14 & -32.62 & $\begin{array}{c}- \\
27.17\end{array}$ \\
\hline 10.Yaks & - & - & 50.00 & 33.33 & 225.00 & 0.00 & -69.23 & 50.00 & 0.00 & 0.00 & 28.00 & -7.23 \\
\hline $\begin{array}{l}\text { 11.Total } \\
\text { Livestoc } \\
\mathbf{k}\end{array}$ & 4.71 & 9.39 & 2.59 & 2.76 & 4.36 & 13.71 & 6.13 & 5.74 & 3.09 & -0.08 & 9.22 & -3.33 \\
\hline $\begin{array}{l}\text { 12.Poultr } \\
\mathrm{y}\end{array}$ & 28.98 & 20.46 & 1.05 & 20.02 & 14.95 & 30.49 & 32.53 & 11.53 & 13.20 & 40.68 & 32.68 & 12.39 \\
\hline
\end{tabular}

Table 3

\begin{tabular}{|c|c|c|c|c|c|c|c|c|c|c|c|c|c|}
\hline \multicolumn{14}{|c|}{ Livestock \& Poultry Population During 1951-2012-All India } \\
\hline \multicolumn{14}{|c|}{ ( In Million Numbers ) } \\
\hline $\begin{array}{c}\text { Spec } \\
\text { ies }\end{array}$ & 1951 & 1956 & 1961 & 1966 & 1972 & 1977 & 1982 & 1987 & 1992 & 1997 & 2003 & 2007 & 2012 \\
\hline $\begin{array}{l}1 . \\
\text { Cattl } \\
\mathrm{e}\end{array}$ & $\begin{array}{c}155.3 \\
0\end{array}$ & $\begin{array}{c}158.7 \\
0\end{array}$ & 175.60 & 176.20 & 178.30 & 180.00 & 192.45 & 199.69 & 204.58 & 198.88 & $\begin{array}{c}185.1 \\
8\end{array}$ & 199.08 & $\begin{array}{c}190.9 \\
0\end{array}$ \\
\hline $\begin{array}{l}2 . \\
\text { Buff } \\
\text { aloes }\end{array}$ & 43.40 & 44.90 & 51.20 & 53.00 & 57.40 & 62.00 & 69.78 & 75.97 & 84.21 & 89.92 & 97.92 & 105.34 & $\begin{array}{c}108.7 \\
0\end{array}$ \\
\hline $\begin{array}{l}3 . \\
\text { Shee } \\
\text { p }\end{array}$ & 39.10 & 39.30 & 40.20 & 42.40 & 40.00 & 41.00 & 48.76 & 45.70 & 50.78 & 57.49 & 61.47 & 71.56 & 65.07 \\
\hline $\begin{array}{l}4 . \\
\text { Goat } \\
\text { s }\end{array}$ & 47.20 & 55.40 & 60.90 & 64.60 & 67.50 & 75.60 & 95.25 & 110.21 & 115.28 & 122.72 & $\begin{array}{c}124.3 \\
6\end{array}$ & 140.54 & $\begin{array}{c}135.1 \\
7\end{array}$ \\
\hline $\begin{array}{l}5 . \\
\text { Hors } \\
\text { es \& } \\
\text { ponie } \\
\text { s } \\
\end{array}$ & 1.50 & 1.50 & 1.30 & 1.10 & 0.90 & 0.90 & 0.90 & 0.80 & 0.82 & 0.83 & 0.75 & 0.61 & 0.63 \\
\hline $\begin{array}{l}6 . \\
\text { Cam } \\
\text { els }\end{array}$ & 0.60 & 0.80 & 0.90 & 1.00 & 1.10 & 1.10 & 1.08 & 1.00 & 1.03 & 0.91 & 0.63 & 0.52 & 0.40 \\
\hline $\begin{array}{l}. \\
\text { Pigs }\end{array}$ & 4.40 & 4.90 & 5.20 & 5.00 & 6.90 & 7.60 & 10.07 & 10.63 & 12.79 & 13.29 & 13.52 & 11.13 & 10.29 \\
\hline $\begin{array}{l}8 . \\
\text { Mule } \\
\text { s }\end{array}$ & 0.06 & 0.04 & 0.05 & 0.08 & 0.08 & 0.09 & 0.13 & 0.17 & 0.19 & 0.22 & 0.18 & 0.14 & 0.20 \\
\hline $\begin{array}{l}9 . \\
\text { Donk } \\
\text { eys }\end{array}$ & 1.30 & 1.10 & 1.10 & 1.10 & 1.00 & 1.00 & 1.02 & 0.96 & 0.97 & 0.88 & 0.65 & 0.44 & 0.32 \\
\hline $\begin{array}{l}10 . \\
\text { Yaks }\end{array}$ & $\mathrm{NC}$ & $\mathrm{NC}$ & 0.02 & 0.03 & 0.04 & 0.13 & 0.13 & 0.04 & 0.06 & 0.06 & 0.06 & 0.08 & 0.08 \\
\hline
\end{tabular}




\begin{tabular}{|c|c|c|c|c|c|c|c|c|c|c|c|c|c|}
\hline \multicolumn{14}{|c|}{ Table 3: contd., } \\
\hline $\begin{array}{l}11 . \\
\text { Tota } \\
\text { I } \\
\text { Live } \\
\text { stock }\end{array}$ & $\begin{array}{l}292.8 \\
0\end{array}$ & $\begin{array}{l}306.6 \\
0\end{array}$ & 335.40 & 344.10 & 353.60 & 369.00 & 419.59 & 445.29 & 470.86 & 485.39 & $\begin{array}{l}485.0 \\
0\end{array}$ & 529.70 & $\begin{array}{l}512.0 \\
6\end{array}$ \\
\hline $\begin{array}{l}12 . \\
\text { Poult } \\
\text { ry }\end{array}$ & 73.50 & 94.80 & 114.20 & 115.40 & 138.50 & 159.20 & 207.74 & 275.32 & 307.07 & 347.61 & $\begin{array}{l}489.0 \\
1\end{array}$ & 648.83 & $\begin{array}{l}729.2 \\
1\end{array}$ \\
\hline
\end{tabular}


